\title{
MINAT MAHASISWA PENDIDIKAN TEKNIK BANGUNAN TERHADAP JASA KONSTRUKSI TEKNIK SIPIL
}

\author{
Renata Shinta G. Simamora, Amos Neolaka, Dadang Suyadi
}

\begin{abstract}
The objective of this study to find out the percentage of Interest of Educational civil engineering with engineering construction services. The study was conducted in May-July 2012. The methods used to determine the percentage of student interest in construction services is a descriptive study with survey methods or qualitative approach method then it doesn't test the hypothesis.

This research was conducted on student of civil engineering State University of Jakarta amounted 360 undergraduate student Population enrolled in semester 096 (2011/2012), with a total sample of 50 students. Determination of samples used Random Sampling with Statified picked up 14\% of the total population. Instruments in this research is non-test instrument. Testing instruments reabilitas questionnaire results obtained by 0.91 meaning belongs to the category of high reability.

The results of Interest of Educational civil engineering with engineering construction services based on interest indicator from the desire of students is $32.68 \%$ Medium Interests category, an interest indicator of kinds activities is a $63.78 \%$ interest in the medium category, an interest indocator effort was $34.84 \%$ interest in the medium category, and results obtained on the terms of the average percentage of students was $132.8 \%$ interest in the category of Medium Interests.
\end{abstract}

Keywords : interest in construction services, civil engineering, Student of PTB

\begin{tabular}{|c|c|c|}
\hline $\begin{array}{l}\text { Rhenata Shinta G. Simamora } \\
\text { Alumni Jurusan Teknik Sipil } \\
\text { Fakultas Teknik } \\
\text { Universitas Negeri Jakarta, } 13220\end{array}$ & $\begin{array}{c}\text { Prof. Dr. Amos Neolaka } \\
\text { Jurusan Teknik Sipil } \\
\text { Fakultas Teknik } \\
\text { Universitas Negeri Jakarta,13220 } \\
\text { email:amos_neolaka@yahoo.com }\end{array}$ & $\begin{array}{r}\text { Drs. Dadang Suyadi, MS } \\
\text { Jurusan Teknik Sipil } \\
\text { Fakultas Teknik } \\
\text { Universitas Negeri Jakarta, } 13220\end{array}$ \\
\hline
\end{tabular}




\section{PENDAHULUAN}

Kemajuan di era globalisasi saat ini telah menjangkau berbagai aspek kehidupan, sehingga persainganpun semakin tajam. Dunia pendidikan sebagai salah satu bagian yang juga mengalami hal yang sama. Agar suatu lembaga pendidikan dapat memiliki keunggulan dalam skala global, maka lembaga pendidikan tersebut harus mampu melakukan pengelolaan secara lebih baik dalam rangka menghasilkan lulusan yang berkualitas.

Kondisi seperti tersebut perlu diantisipasi lebih dini oleh lembaga pendidikan, penyelenggaraan proses pembelajaran di dunia pendidikan dilaksanakan dengan beberapajenjang mulai dari pendidikan dasar sampai tinggi. Lembagapendidikan adalah wadah atau tempat yang menciptakan hal-hal yang berhubungan dengan kemajuan ilmu pengetahuan dan teknologi, serta tujuan meningkatkan kualitas hidup manusia.

Jenjang Perguruan Tinggi merupakan jenjang yang ditempuh setelah seseorang lulus dari SMU atau SMK, untuk masuk ke perguruan tinggi baik yang dimiliki Pemerintah maupun swasta. Visi dan Misi Perguruan Tinggi Universitas Negeri Jakarta (UNJ).Visi: Menjadi universitas yang memiliki keunggulan kompetitif dalam membangun masyarakat Indonesia yang maju, demokratis dan sejahtera berdasarkan Pancasila di era globalisasi. Misi: (1)Mengembangkan ilmu pengetahuan, teknologi, dan seni yang dapat meningkatkan kualitas hidup manusia dan lingkungan; (2) Menyiapkan tenaga akademik dan/atau profesional yang bermutu, bertanggung jawab dan dan mandiri di bidang pendidikan dan nonkependidikan guna menghadapi berbagai tantangan di masa depan; (3) Mengembangkan ilmu dan praksisi kependidikan dalam rangka mempercepat pencapaian pendidikan nasional; (4) Mengembangkan berbagai bentuk pengabdian kepada masyarakat dibidang ilmu, teknologi dan seni yang berdaya guna dan berhasil guna; (5) Menciptakan budaya ekonomi yang kondusif bagi pemberdayaan semua potensi kemanusiaan yang optimal dan terintegrasi secara berkesinambungan; (6) Memfungsikan dirinya selaku universitas yang mampu menerapkan prinsip-prinsip entrepeneurship dalam kinerjanya secara berkesinambungan.

UNJ mengemban fungsi untuk mengembangkan potensi sumber daya manusia di bidang kependidikan dan non-kependidikan yang mandiri dan memiliki integritas sesuai dengan tuntutan pembangunan yang berkesinambungan. Seiring dengan berkembangnya zaman dan peningkatan daya saing secara global yang menyebabkan semakin pesatnya kemajuan teknologi yang menuntut sumber daya manusia berkualitas dalam bekerja sesuai dengan bidangnya masing-masing.

UNJ memiliki beberapa jurusan yang dibedakan sesuai dengan bidang keahlian salah satunya adalah jurusan Teknik Sipil. Pada jurusan ini terdapat Program Studi Pendidikan Teknik Bangunan yang diharapkan menghasilkan lulusan yang berkualitas untuk menjadi tenaga kerja sesuai dengan kompetensi lulusan. 
Oleh karena itu perguruan tinggi sebagai lembaga pendidikan melaksanakan fungsi Tridharma Perguruan Tinggi yaitu: pendidikan, penelitian dan pengabdian kepada masyarakat, serta mengelola Iptek. Universitas Negeri Jakarta (UNJ) merupakan salah satu perguruan tinggi di Indonesia yang mencetak lulusan tenaga kependidikan.

Dalam rangka mengaplikasikan visi dan misi teknik sipil FT-UNJ dan tercapinya tujuan pendidikan, mahasiswa diharapkan terlebih dahulu memenuhi atau mempersiapkan diri sehingga nantinya dapat tercipta mahasiswa yang siap untuk terjun dalam dunia pembangunan yang mantap dan dinamis dalam dunia kerja, Iulusan Program Studi Pendidikan
Teknik Bangunan berkualitas dan dapat bersaing di dunia kerja baik di bidang kependidikan maupun di bidang non kependidikan.

Terdapat beberapa fenomena yang membuat alumni dan mahasiswa yang bingung dan sedih bahwaberdasarkan data DEPDIKNAS, SMK di DKI Jakarta telah mengalami pengurangan. Dikarenakan makin sedikitnya jumlah Sekolah Mengengah Kejuruan (SMK), khususnya jurusan teknik bangunan. Data yang diperoleh di Jakarta hanya terdapat 7 Sekolah Menengah Kejuruan (SMK) yang memiliki jurusan berkaitan dengan teknik bangunan. Data terlihat pada tabel 1.1 sebagaimana data dapat dilihat seperti berikut:

Tabel 1. Daftar SMK di Jakarta yang memiliki Jurusan Berkaitan dengan Teknik Bangunan.

\begin{tabular}{|c|c|c|}
\hline $\begin{array}{c}\text { NAMA } \\
\text { SEKOLAH }\end{array}$ & ALAMAT & KOMPETENSI KEAHLIAN \\
\hline SMKN. 1 & $\begin{array}{l}\text { JI. Budi Utomo No. 7, Jakarta } \\
\text { Pusat }\end{array}$ & Tek. Konstruksi Kayu \\
\hline SMKN 4 & Jl. Rorotan 6, Jakarta Utara & $\begin{array}{l}\text { Tek. Konstruksi Batu dan Beton (TKBB) } \\
\text { Teknik Kontruksi Kayu (TKK) }\end{array}$ \\
\hline SMKN 56 & $\begin{array}{l}\text { Jl. Raya Pluit Tmur no.1, } \\
\text { Jakarta Utara }\end{array}$ & Teknik Bangunan (TB) \\
\hline SMKN 35 & $\begin{array}{l}\text { Jl. Kerajinan No. 42, Jakarta } \\
\text { Barat }\end{array}$ & $\begin{array}{l}\text { Tek. Gambar Bangunan (TGB) } \\
\text { Tek. Konstruksi Kayu (TKK) }\end{array}$ \\
\hline SMKN 26 & $\begin{array}{l}\text { Jl. Balai Pustaka Baru 1, } \\
\text { Jakarta Timur }\end{array}$ & Tek. Gambar Bangunan (TGB) \\
\hline SMKN 52 & $\begin{array}{l}\text { Jl. Pusdika Cibubur, Jakarta } \\
\text { Timur }\end{array}$ & $\begin{array}{l}\text { Tek. Gambar Bangunan (TGB) } \\
\text { Tek. Perkayuan (TP) }\end{array}$ \\
\hline SMKN 58 & Jl. Bambu Apus, Jakarta Timur & $\begin{array}{l}\text { Kria Kayu ( KK ) } \\
\text { Tek. Bangunan/Perkayuan }\end{array}$ \\
\hline
\end{tabular}

Berdasarkan data tabel diatas SMK Jurusan TeknikBangunan lebih terfokus kepada Teknik Perkayuan atau Menggambar Bangunan saja dan sangat sedikitnya SMK Jurusan Teknik Bangunan khususnya di Jakarta dan membuat mahasiswa untuk menjadi seorang pendidik merasa tersudut. Mahasiswa merasa bahwa Iulusan Program Studi Pendidikan Teknik Bangunan untuk menjadi guru atau tenaga pengajar peluangnya sangat sedikit jadi apakah 
fungsi dari gelar yang diperoleh setelah lulus yaitu Sarjana Pendidikan (S.Pd).

Pembangunan nasional tidak bisa dipisahkan dari penyelenggaraan konstruksi suatu investasi pembangunan berbagai jenis infrastruktur dan properti. Penyelenggaraan konstruksi telah menjadi salah satu sektor penting dari perekonomian nasional baik di negara-negara maju apalagi negara-negara yang sedang berkembang.

Oleh karena itu bangsa-bangsa di dunia tidak hanya meggunakan kaca mata sempit untuk melihat konstruksi dan memastikan bahwa penyelenggaraan konstruksi bukan "hanya tukang" tetapi suatu sektor yang menyelenggarakan mata rantai kegiatan ekonomi.

Pekerjaan dalam industri bangunan seperti sebagai (engineering, quantity surveyor, supervisor, estimator, drafter, dll) yang memiliki peluang lebih banyak dibandingkan dunia kerja dibidang kependidikan. Akan tetapi pandangan bahwa lulusan teknik bangunan yang bekerja didunia kontraktor sudah menjadi rahasia umum, bahwa bekerja di dunia teknik sipil itu penuh ketidak jujuran, seperti untuk memenangkan tender akan menghalalkan segala cara, memanipulasi data agar dapat untung besar, dan banyak citra negatifnya.

Penelitian tentang Penelusuran Iulusan Program Studi Pendidikan Teknik Bangunan (Skripsi Ria Riantika. 2012), penelitian tentang klasifikasi bidang pekerjaan lulusan Program Studi Pendidikan Teknik Bangunan FT UNJ lebih banyak ke non-kependidikan, yang tidak sesuai dengan gelar yang diperoleh oleh mahasiswa lulusa Teknik Sipil yaitu Sarjana Pendidikan (S.Pd).

Untuk membuktikan ungkapan di atas secara konkrit perlu diungkapkan fakta, berdasarkan dari masalah yang penulis ingin teliti memilih judul: Studi Minat Mahasiswa Pendidikan Teknik Bangunan terhadap Jasa Konstruksi Teknik Sipil (Studi Deskriptif Mahasiswa Program Studi Pendidikan Teknik Bangunan FT-UNJ)

\section{Tinjauan Pustaka}

Minat

Dalam Kamus Besar Bahasa Indonesia (KBBI) minat diartikan sebagai kecenderungan hati yang tinggi terhadap sesuatu, gairah, keinginan (Depdikbud,1991:656). Beberapa ahli psikologi memberikan pendapat mengenai definisi minat yang pada dasarnya mempunyai makna yang sama, namun memberikan penekanan yang berbeda.

Sepert minat yang dimiliki oleh setiap individu berbeda-beda. Demikian halnya antara mahasiswa yang satu dengan yang lainnya mempunyai keragaman minat, meskipun mereka berada dalam satu lembaga yaitu Fakultas Teknik program studi Pendidikan Teknik Bangunan FT-UNJ. Untuk mengetahui lebih jelas apa yang dimaksud dengan minat berikut ini disajikan pendapat para ahli.

Menurut Whitterington, minat adalah kesadaran seseorang, bahwa suatu objek, seseorang, suatu soal atau suatu situasi mengandung sangkut paut dengan dirinya (Whitterington,1985). Ini berarti minat bisa timbul bila ada sesuatu yang merangsang pada diri seseorang kemudian mendapat respon. 
Wingkel berpendapat minat merupakan kecenderungan yang agak menetap dalam diri subjek, sehingga ia merasa tertarik pada suatu bidang atau hal-hal tertentu, dan merasa senang berkecimpung di dalam bidang atau hal tersebut (W.S.Wingkel,1985), karena begitu pentingnya peran minat dalam kehidupan seseorang, sehingga minat nantinya akan mempunyai dampak yang besar terhadap sikap dan prilaku seseorang.

Seseorang yang mempunyai minat yang tinggi terhadap sesuatu aktivitas atau kegiatan tertentu, baik itu yang berbentuk permainan ataupun pekerjaan maka ia akan berusaha keras untuk belajar dan aktif dalam aktivitas tersebut, dibandingkan dengan orang yang mempunyai minat yang rendah terhadap aktivitas atau kegiatan. Kemudian Hurlock menjelaskan juga bahwa semua minat mempunyai dua aspek diantaranya adalah:

a. Aspek kognitif, yaitu aspek yang dikembangkan seseorang mengenai bidang yang berkaitan dengan minat. Aspek ini berkembang dari pengalaman pribadi dan apa yang dipelajari di rumah, di sekolah, dan di masyarakat, serta dari berbagai jenis media massa.

b. Aspek afektif, yaitu konsep yang membangun aspek kognitif yang dinyatakan dalam sikap yang ditimbulkan minat (Elizabeth Hurlock, 1990).

Walaupun kedua aspek tersebut penting peranannya dalam menentukan apa yang akan dan yang tidak dikerjakan oleh seseorang, dan jenis penyesuaian pribadi dan sosial mereka, aspek afektif menurut Hurlock lebih besar peranannya. Karena aspek afektif mempunyai peran yang lebih besar dalam memotivasi daripada aspek kognitif dan aspek afektif cenderung lebih tahan terhadap perubahan dibandingkan dengan aspek kognitif.

Minat yang terdiri aspek kognitif dan aspek afektif dapat berkurang dan bertambah sebagaimana yang diungkapkan oleh Crow bahwa seseorang itu hanya memiliki minat sangat sedikit dari bawaannya. Pengalaman yang bermacam- macam sebagai hasil pengamatan lingkungan dapat menyebabkan minat itu berkembang dan berkurang (L.D. Crow,1963).

Menurut Save M. Dagun, Kamus Besar IImu Pengetahuan (Jakarta. Lembaga Kajian Kebudayaan Nasional, 2000) : Minat adalah perhatian, kesukaan, keinginan, kecenderungan tingkah laku seseorang terhadap objek, kegiatan atau pengalaman tertentu; berhubungan dengan (1) intensitas/tingkat keterarahan yang biasanya berbeda dari satu individu dengan individu lainnya, (2) kecakapan yang menentukan tingkat keterbatasan minat, makin rendah kecapakan/intelegensi seseorang, makin rendah minatnya terhadap sesuatu.

Menurut Hilgrad : Memberikan rumusan minat sebagai berikut "Interest is persisting tendency to pay attention to and enjoy some activity or content". Jika diterjemahkan ke dalam Bahasa Indonesia adalah sebagai berikut "Minat adalah kecenderungan yang tetap untuk memperhatikan dan mengenang beberapa kegiatan". 
Menurut H.C. Witherington, terjemahan M. Buchori, Psikologi Pendidikan. (Jakarta; Aksara Baru, 1985): Minat sebagai kesadaran seseorang bahwa suatu objek, seseorang, suatu hal, atau suatu situasi mempunyai sangkut pautnya dengan dirinya. Minat harus dipandang sebagai reaksi sadar, kalau tidak demikian minat itu tidak akan mempunyai arti sama sekali, itu artinya jika seseorang mempunyai minat terhadap sesuatu atau objek berarti bahwa sesuatu atau objek tadi dalam salah satu cara ada sangkut pautnya dengan dirinya.

Menurut Slameto: Minat turut mendorong motivasi perbuatan belajar dan turut menentukan keberhasilan belajar siswa, karena bila bahan pelajaran yang dipelajari tidak sesuai dengan minat siswa, siswa tidak belajar dengan sebaikbaiknya, karena tidak ada daya tarik baginya.

Menurut Muhibbin Syah, Psikologi Pendidikan dan pendekatan baru (bandung, remaja Rosdakarya, 1997): Minat dapat mempengaruhi kualitas pencapaian hasil belajar siswa dalam bidang-bidang studi tertentu. Individu yang menaruh minat besar terhadap sesuatu atau objek akan memusatkan perhatiannya lebih banyak dari pada individu lainnya. Kemudian, karena pemusatan perhatiannya yang intensif terhadap materi itulah yang memungkinkan individu tadi untuk belajar lebih giat dan akhirnya mendapatkan hasil belajar yang diinginkan. Objek dari minat bisa berbagai macam, baik makhluk hidup, aktivitas, benda mati, pekerjaan dan lain-lain.

Menurut Hilgrad, (Slameto, 2010): Mengatakan bahwa minat adalah suatu rasa lebih suka dan rasa ketertarikan pada suatu hal atau aktivitas, tanpa ada yang menyuruh. Pada dasarnya minat merupakan penerimaan akan suatu hubungan antara diri sendiri dengan sesuatu di luar diri. Semakin kuat atau dekat hubungan tersebut, semakin besar minat

Menurut M. Ngaliman Purwanto: Minat mengarah kepada suatu tujuan dan merupakan dorongan bagi perbuatan itu, karena apa yang menarik minat seseorang mendorongnya untuk berbuat lebih baik dan hasil yang lebih baik pula. Dengan kata lain terdapat hubungan yang kuat antara minat dengan hasil belajar dimana keduanya saling mempengaruhi satu sama lain.

Menurut Syaiful bachri Jamara, 2008: Mengemukakan minat sebagai suatu kecenderungan yang menetap untuk memperhatikan dan mengenang beberapa aktivitas.

Pengertian minat telah banyak dikemukakan oleh para ahli psikologi dan pendapat-pendapat para ahli tersebut banyak menekankan pada aspek tertentu yang berbeda satu dengan yang lainnya. Namun demikian pada dasarnya semuanya mengartikan minat sebagai perasaan keterkaitan seseorang terhadap suatu objek atau aktivitas tertentu yang dinyatakan dengan suka atau tidak suka.

Berdasarkan sejumlah kutipan mengenai pengertian minat yang telah dikemukakan di atas maka dapat disimpulkan bahwa minat adalah kecenderungan jiwa yang menimbulkan perasaan suka atau tidak suka, senang atau tidak senang terhadap suatu objek atau aktivitas yang dapat memenuhi kebutuhan serta dapat menyenangkan dirinya. Minat juga turut menentukan keberhasilan seseorang. 


\section{Klasifikasi Minat}

Berikut ini penulis uraikan klasifikasi minat yang dikemukakan oleh para ahli berdasarkan sudut pandang masing-masing :

1) H.C Witherington, membedakan minat menjadi :

a) Minat primitive atau minat biologis bersumber pada soal-soal makanan, kenikmatan dan kebebasan aktivitas. Ketiga hal ini meliputi kesadaran tentang kebutuhan terhadap sesuatu yang secara langsung dapat memuaskan dorongan untuk mempertahankan oganisme.

b) Minat Kultural atau minat sosial adalah minat-minat yang dipelajari. Yaitu minat yang berkembang karena pengaruh budaya atau pendidikan.

2) M. Surya, Dasar-dasar Konseling Pendidikan (Yogyakarta; Kota Kembang, 1988) mengelompokan minat menjadi 3 macam minat yang dikaitkan dengan proses belajar mengajar, yaitu :

a) Minat Volunter ialah minat yang timbul secara sukarela, timbul dengan sendirinya tanpa adanya pengaruh yang sengaja dari luar

b) Minat Involunter ialah minat yang timbul dari diri pelajar dengan adanya pengaru suatu keadaan yang diciptakan oleh pengajar

c) Minat nonvolunter ialah minat yang sengaja dipaksakan atau diharuskan untuk timbul

3) Selanjutnya untuk mengetahui minat seseorang terhadap objek tertentu Super
D.E dan Crites J.O. Aprrasing Vocational Fittnes ( New York : harper \& Row, 1996) mengelompokan dalam empat jenis yaitu:

a) Expressed Interest, yaitu minat yang dapat diketahui dari pernyataan responden (subjek) tentang objek dan pekerjaan yang disenanginya.

b) Manifers Interest, yaitu minat yang dapat diketahui melalui pengamatan terhadap kegiatan-kegiatan yang sering dilakukan subjek.

c) Test Interest, yaitu minat yang dapat diketahui melalui kesimpulankesimpulan dari tes objektif.

d) Inventored Interest, yaitu minat yang dapat diketahui melalui daftar isian yang telah disediakan kemudian subjek akan memilih sesuai dengan minatnya terhadap objek tertentu.

\section{Pertumbuhan dan Perkembangan Minat}

Minat yang dimiliki seseorang dalam setiap waktunya biasa mengalami perubahan, hal ini tergantung pada kondisi fisik, mental dan keadaan emosinya, serta perubahan lingkungan sosial dimana berada. Perubahan-perubahan minat dalam proses tersebut dapat disebabkan oleh perubahan pola kehidupan, perubahan tugas, dan tanggung jawab serta perubahan status sosial.

Sebelum menginjak masa remaja seseorang akan mengalami proses perubahan minat yang begitu cepat. Namun demikian diakhir masa remaja, minat itu sudah relatif tetap. Perubahan minat sangat erat kaitannya dengan perkembangan pola prilaku sosial pengaruh lingkungannya. 
Menurut Crites, O. Jhon, Vacational Psychology. (Mc. Graw Book Company: 1969) mengemukakan bahwa dua pertiga dari perubahan yang terjadi berlangsung antara umur 15 hingga 18 tahun, sedang sepertiganya berlangsung antara umur 16 hingga 25 tahun. Pada masa kanak-kanak, baik pria maupun wanita sangan senang bermain dengan mainan yang sederhana dan masing-masing anak cenderung aktif dengan caranya sendiri sesuai dengan minatnya pada saat itu. Dia ingin belajar mengenai apa yang membuat segala sesuatu itu terjadi. Mulai tertarik pada orang, tempat serta kondisi di luar lingkungan dimana ia berada.

Menurut Elizabeth B. Hurlock, Psikologi Perkembangan Suatu pendekatan Sepanjang Kehidupan (Jakarta: Erlangga, 1980): Pada waktu menginjak masa remaja, aktivitas utama dipusatkan di sekeliling dirinya, pengajaran nilainilai sosial serta kesempatan pribadi.

Minat pribadi timbul karena mereka sadar bahwa dukungan sosial sangat besar dipengaruhi oleh penampilan diri dan mengetahui bahwa sekelompok sosial menilai dirinya berdasarkan benda-benda yang dimiliki, kemandirian, sekolah, keanggotaan sosial dan banyak uang yang dibelanjakan. Ini adalah "simbol status" yang mengangkat wibawa remaja diantara teman-teman sebaya dan memperbesar kesempatan untuk memperoleh dukungan sosial yang lebih besar.

Pada akhir masa remaja minat pada karier seringkali menjadi sumber pikiran. seperti yang di terangkan oleh Thomas yang dikutip Elizabeth B. Hurlock bahwa, pada saat tersebut remaja belajar membedakan antara pilihan pekerjaan yang lebih disukai dan pekerjaan yang dicita-citakan. Remaja yang lebih tua lebih memikirkan apa yang akan dilakukan dan apa yang mampu dilakukan. Semakin mereka mendengar dan membicarakan berbagai jenis pekerjaan, semakin ia kurang yakin mengenai apa yang akan dilakukan. Remaja juga memikirkan cara untuk memeroleh pekerjaan yang diinginkan.

Memasuki masa dewasa, minat lebih ditekankan pada hal-hal yang menunjang kehidupan keluarga seperti uang dan rumah. Sejalan dengan perubahan pola kehidupan orang dewasa, dapat pula terjadi perubahan minat baik itu yang merupakan perubahan jumlah yang diminati, pergeseran hal-hal yang diutamakan, dan bahkan mungkin timbul minat baru. Elizabeth B. Hurlock mengemukakan bahwa perkembangan minat yang cukup berarti, tidak hanya terjadi selama masa kanak-kanak dan awal masa remaja, namun juga selama menginjak usia dewasa.

\section{Faktor-Faktor yang Mempengaruhi Minat} Proses pertumbuhan dan perkembangan minat terjadi sepanjang garis kehidupan seseorang walaupun telah dewasa. Proses tersebut diantaranya dipengaruhi oleh beberapa faktor, pendapat Blair yang dikutip oleh Heni Wahyuwidiyanti, Minat Belajar Siswa Ditinjau Dari Suasana Intelektual Keluarga (Skripsi: 1992), menyatakan bahwa proses pertumbuhan dan perkembangan minat dipengaruhi oleh beberapa faktor diantaranya: ragamnya kebutuhan, keinginan dan cita-cita, kebudayaan dan lingkungan, kesempatan dan pengalaman. 
Setiap individu memiliki keragaman kebutuhan, untuk memenuhi kebutuhan tersebut ia cenderung tertarik pada objek yang disukai dan member kekuasaan bagi dirinya. L.L. Pasaribu. B. Simanjuntak, Didaktik dan Metodik (Bandung; Tarsito 1986) berpendapat bahwa minat berhubungan dengan kebutuhan. Menurut Reber yang di kutip Muhibbin Syah, mengemukakan bahwa minat tidak termasuk istilah popular dalam psikologi karena ketergantungannya yang banyak pada faktorfaktor internal lainnya seperti pemusatan perhatian, keingintahuan, motivasi dan kebutuhan.

Berasarkan pendapat tersebut di atas, bahwa ragamnya kebutuhan akan memperngaruhi minat individu. Dengan demikian minat akan berhubungan dengan pekerjaan, pendapat dan peningkatan kecakapan seseorang sebagai bekal untuk kehidupannya.

\section{Macam-macam Minat}

Secara konseptual Krapp dalam Suhartini, 2001 mengkategorikan minat menjadi 3 dimensi yaitu :

1) Minat Personal

Minat Personal terkait erat dengan sikap dan motivasi atas mata pelajaran tertentu, apakah dia tertarik atau tidak, apakah dia senang atau tidak, dan apakah dia mempunyai dorongan keras dari dalam dirinya untuk menguasai mata pelajaran tersebut. Minat personal identik dengan minat intrinstik yang mengarah pada minat khusus pada ilmu sosial, olah raga, sains, musik, kesastraan, komputer, dan lain sebagainya.
2) Minat Situasional

Minat Situasional menjurus pada minat siswa yang tidak stabil dan relatif berganti-ganti tergantung dari faktor rangsangan dari luar dirinya. Misalnya suasana kelas, cara mengajar, dorongan keluarga. Minat situasional ini merupakan kaitan dengan pelajaran yang diberikan.

3) Minat Psikologikal

Minat Psikologikal erat kaitannya dengan adanya sebuah interaksi antara minat personal dan minat situasional yang terus menerus dan berkesinambungan.

\section{Indikator-Indikator Minat}

Indikator minat dapat dilihat dengan cara menganalisa kegiatan-kegiatan yang dilakukan individu, objek yang disenanginnya, karena minat merupakan motif yang dipelajari yang mendorong dan mengarahkan individu untuk menemukan secara aktif dalam kegiatankegiatan tertentu. Ada beberapa hal yang menjadi indikator dari minat. Suhartini (2001) menganalisa beberapa hal yang menjadi indikator minat :

1) Keinginan untuk mengetahui atau memiliki sesuatu objek yang diminatinya

2) Objek atau alat kegiatan yang disenangi

3) Upaya-upaya atau usaha yang dilakukan untuk merealisasikan keinginan atau rasa senang terhadap objek atau keinginan tertentu.

Hal di atas sesuai dengan yang dikemukakan oleh Slameto (2010) mengatakan bahwa suatu minat dapat diekspresikan melalui suatu pernyataan yang menunjukan bahwa anak didik lebih menyukai suatu hal daripada hal 
lainnya, dapat pula melalui partisipasi dalam suatu aktivitas yang memiliki minat terhadap subjek.

\section{Pengukuran Minat}

Minat merupakan salah satu faktor yang turut menentukan keberhasilan seseorang. Untuk itu pengukuran minat dirasakan penting adanya.

Sehubungan dengan pengukuran minat, ada beberapa metode yang digunakan untuk mengadakan pengukuran minat seperti yang dikemukakan oleh Wayan Nurkancana dan P.P.N Sumartana (1986) diantaranya:

1) Observasi

Pengukuran minat dengan metode observasi mempunyai suatu keuntungan karena dapat mengamati dalam kondisi yang wajar, jadi tidak dibuat-buat. Observasi dapat dilakukan dalam setiap situasi, baik dalam perkuliahan maupun luar perkuliahan.

2) Wawancara (Interview)

Metode wawancara baik digunakan untuk mengukur minat mahasiswa sebab biasanya mahasiswa gemar memperbincang-bincangkan hobinya dan aktivitas lain yang menarik haatinya. Pelaksanaan interview sebaiknya dilakukan dalam situasi yang sangat formal sehingga lebih bebas, misalnya pada waktu istirahat, diluar jam pelajaran, kunjuangan kerumah, dll.

3) Kuesioner

Dengan metode kuesioner dapat dilakukan pengukuran minat terhadap sejumlah orang sekaligus. Kuesioner jauh lebih efisien daripada observasi dan interview dalam pengukuran waktu. Isi pertanyaan yang diajukan pada prinsipnya tidak berbeda dengan metode interview.

Perbedaan dengan interview adalah interview dilakukan dengan secara lisan, sedangkan kuesioner dilakukan dengan secara tertulis dan bertanya secara langsung dengan beberapa orang sekaligus.

4) Inventori

Inventori adalah suatu metode untuk mengadakan pengukuran atau penilaian yang sejenis dengan kuesioner, yaitu samasama merupakan daftar pertanyaan secara tertulis. Dari daftar pertanyaan tersebut responden diminta untuk memilih statmen yang cocok dengan dirinya.

Perbedannya adalah dalam kuesioner instrumennya berupa daftar pertanyaan yang harus dijawab oleh responden, sedangkan pada inventori instrumennya berupa daftar statemen yang harus dipilih oleh responden sesuai dengan keadaan dirinya.

\section{METODE PENELITIAN}

Menurut Masri Singarimbun dkk (1995) penelitian merupakan suatu proses yang panjang untuk mengetahui fenomena tertentu. Menurut Nawawi (1995) metode deskriptif dengan pendekatan survei adalah suatu metode untuk menggambarkan dan melukiskan keadaan suatu obyek penelitian pada saat sekarang berdasarkan fakta-fakta yang tampak sebagaimana adanya. 
Kuesioner tersebut berfungsi untuk menggali informasi sebanyak-banyaknya mengenai minat mahasiswa program studi pendidikan teknik bangunan terhadap jasa konstruksi teknik sipil.

Penelitian deskriptif dimaksudkan untuk pengukuran yang cermat terhadap output dan outcome. Output (keluaran) berkaitan dengan informasi hasil akhir setelah suatu kuisioner yang diberikan kepada responden. Sedangkan yang dimaksud dengan data yang diambil dari outcome (hasil) adalah pengaruh suatu perlakuan.

Penelitian ini bertujuan untuk menggambarkan situasi-situasi sosial sehubungan dengan, (1) Untuk mengetahui pengetahuan mahasiswa tentang jurusan teknik bangunan, dan (2) Untuk mengetahui minat mahasiswa terhadap dunia jasa konstruksi teknik sipil, sebagai orang yang menggeluti bidang teknik sipil sebagai pilihanya. Penelitian ini merupakan penelitiaan deskriptif dengan metode survei menggunakan perhitungan skala likert.

Seperti dikutip Moleong dalam Yuli Kwartolo (2010), mendefinisikan penelitian kualitatif sebagai prosedur penelitian yang menghasilkan data deskriptif berupa kata-kata tertulis atau lisan dari orang-orang dan prilaku yang dapat diamati. Pendapat lain dikemukakan oleh Denzin dan Lincoln yang juga dikutip oleh Yuli Kwartolo (2010), bahwa penelitian kualitatif adalah penelitian yang menggunakan latar alamiah, dengan maksud menafsirkan fenomena yang terjadi dengan jalan melibatkan berbagai metode yang ada.
Dengan skala likert, maka variabel yang akan diukur dijabarkan menjadi indikator variabel. Kemudian indikator tersebut dijadikan sebagai titik tolak untuk menyusun item-item instrumen yang dapat berupa pernyataan atau pertanyaan, baik bersifat favorable (positif) maupun bersifat unfavorable (negatif).

Instrumen-instrumen penelitian sudah ada yang dibakukan, tapi ada yang harus dibuat peneliti sendiri. Karena instrumen penelitian akan digunakan untuk melakukan pengukuran dengan tujuan menghasilkan data kuantitatif yang akurat, maka setiap istrumen harus mempunyai skala.

\section{HASIL DAN PEMBAHASAN}

Berdasarkan pengolahan kuesioner minat mahasiswa PTB terhadap jasa konstruksi dengan menggunakan skala likert yaitu dengan skala 1-5 untuk pernyataan positif ( $1=$ sangat setuju, 2= setuju , 3= ragu-ragu, 4= tidak setuju, $5=$ sangat tidak setuju) dan skala 1-5 untuk pernyataan negatif $(1=$ sangat tidak setuju, $2=$ tidak setuju, $3=$ ragu-ragu, $4=$ setuju, $5=$ sangat setuju). Berdasarkan pengolahan data mengenai minat mahasiswa pendidikan teknik bangunan terhadap jasa konstruksi diperoleh hasil sebagai berikut:

Rerata yang diperoleh dari 50 responden (Mahasiswa yang terdaftar pada semester 096) diperoleh skor 132,8 yang masuk dalam intepretasi Minat Sedang.

\section{Pembahasan Hasil Penelitian}

Berdasarkan dari hasil pengolahan data dan kajian pustaka yang relevan, pembahasan hasil penelitian ini dimaksudkan untuk 
memberikan gambaran secara terperinci, jelas dan terarah

Minat adalah suatu kecenderungan seseorang dalam bertingkah laku yang dapat diarahkan untuk memperhatikan sesuatu objek atau melakukan suatu aktivitas tertentu yang didorong oleh perasaan senang karena dianggap bermanfaat bagi dirinya.

Pada penelitian ini yang diteliti adalah minat mahasiswa pendidikan teknik bangunan terhadap jasa konstruksi teknik sipil. Hal ini menggambarkan bahwa tujuan dari Program Studi Pendidikan Teknik Bangunan belum tercapai secara utuh, yang pada awalnya mempunyai tujuan untuk mencetak dan menghasilkan tenaga pendidik/guru yang profesional, namun pada kenyataannya terdapat mahasiswa yang mempunyai minat selain bidang pendidikan dan masuk dalam kategori minat tinggi.

Hal ini bisa saja terjadi karena berbagai faktor seiring dengan perjalanan mahasiswa dalam menempuh pendidikannya. Perubahan minat tersebut bisa saja terjadi karena pada saat di bangku kuliah mahasiswa lebih sering berhubungan dengan bidang keteknik sipilan dari pada bidang kependidikan, seperti beban sks yang ternyata mata kuliah keteknik sipilan mempunyai bobot Sistem Kredit Semester (SKS) lebih besar dari pada mata kuliah kependidikan. Selain itu, mahasiswa di kampus juga lebih sering mengikuti kegiatan di bidang teknik sipil baik berupa kunjungan studi, studium general, seminar maupun kegiatan lainnya.

Sementara itu kegiatan di bidang kependidikan sangat jarang sekali dilakukan. Hal ini secara tidak langsung dapat membuat mahasiswa terpengaruh untuk lebih menyukai bidang keteknik sipilan karena mereka lebih sering berjumpa dengan bidang keteknik sipilan dari pada bidang kependidikan.

digambarkan bahwa responden dari semua angkatan interpretasi minat tinggi terhadap jasa konstruksi teknik sipil. Dari hasil penelitian mengenai minat mahasiswa Pendidikan Teknik Bangunan proses pembentukan minat berkaitan erat dengan menetapkan kesukaan dan ketidaksukaan seseorang terhadap suatu objek/kegiatan yang timbul dari pengalaman-pengalaman atau informasi-informasi yang diperoleh.

Para ahli berpendapat bahwa minat berkembang dan menguat pada diri seseorang sejalan dengan bertambahnya usia orang tersebut. Sebelum masa remaja, minat dapat berubah dengan cepat. Namun di akhir masa remaja minat mempunyai kecenderungan untuk stabil.

\section{Keterbatasan Penelitian}

Walaupun penelitian ini telah dilakukan secara optimal untuk mengetahui hasil pencapaian akhir penelitian yang diharapkan, namun demikian penulis menyadari dalam penelitian ini ada suatu keterbatasan yang sulit untuk dihindari.

Adapun keterbatasan dari penelitian ini antara lain:

a. Instrumen penelitian ini berupa kuisioner atau angket, dan responden dalam memberikan jawaban hanya berdasarkan pada beberapa alternatif yang disediakan peneliti saja. Hal tersebut akan berdampak 
pada kebebasan responden dalam memberikan tanggapannya terhadap halhal yang mungkin tidak sesuai dengan kondisi yang sebenarnya terjadi atau yang dialami responden di dalam kelas.

b. Pengambilan data menggunakan angket dengan tenggang waktu cukup sedikit memungkinkan responden untuk memikirkannya lebih cepat, hal ini dapat berdampak negatif, sebab dengan kurangnya tenggang waktu membuat responden bersikap memilih alternatif jawaban yang tidak sesuai dengan keadaan sebenarnya.

c. Masih terdapat butir-butir yang belum mewakili semua aspek materi dalam indikator dalam kuesioner minat mahasiswa terhadap jasa konstruksi.

\section{KESIMPULAN}

Berdasarkan hasil penelitian setelah melalui berbagai tahap, yaitu proses instrumenisasi, uji coba instrumen, pengumpulan data, analisis data, serta penafsiran terhadap hasil analisis data, mengenai minat mahasiswa Pendidikan Teknik Bangunan FT-UNJ. Maka berdasarkan hasil penelitian dapat disimpulkan bahwa minat mahasiswa terhadap jasa konstruksi termasuk dalam persentase Minat Mahasiswa Pendidikan Teknik Bangunan terhadap Jasa Konstruksi Tenik Sipil adalah sebagai berikut:

a. Minat dari masing-masing responden tidak sama, dikarenakan perbedaan pola pikir, keinginan dan usaha-usaha terhadap jasa konstruksi teknik sipil. Hasil perhitungan rerata persentasi minat mahasiswa berdasarkan indikator minat mendapatkan Persentase Minat Sedang.

b. Proses perkuliahan sebagai suatu ajang peningkatan minat dan kemampuan mahasiswa, memberikan pengetahuan atau wawasan untuk dapat mengaplikasikan ilmu yang telah diperoleh serta untuk mengembangkan ilmu yang dimiliki dalam dunia jasa konstruksi.

\section{Implikasi}

Berdasarkan analisis terhadap variabel yang diteliti, diketahui bahwa persentase minat terhadap jasa konstruksi dalam kategori Minat Tinggi. Oleh sebab itu, upaya sosialisasi tentang jasa konstruksi, baik dalam bentuk mengembangkan tingkatan pengetahuan tentang jasa konstruksi bagi mahsiswa. Agar Sumber Daya Manusia (SDM) yang dihasilkan juga berkualitas dan profesional. Guna calon penerus generasi dalam bekerja pada bidang jasa konstruksi dikarenakan telah memiliki bekal cukup dan siap dalam dunia kerja khususnya dalam bidang jasa konstruksi.

\section{Saran}

Berdasarkan kesimpulan yang telah dipaparkan di atas, berikut ini dikemukakan beberapa saran terkait dengan simpulan tersebut, yaitu :

Jurusan Teknik Sipil FT-UNJ diharapkan dapat terus menciptakan lulusan yang profesional, serta mengarahkan dan meningkatkan minat 
lulusannya untuk menjalani profesi yang sesuai dengan kemampuan dan kepribadiannya.

a. Mahasiswa hendaknya lebih meningkatkan pengetahuan mata kuliah jurusan yang bertujuan untuk bekal pengetahuan yang akan diaplikasikan nantinya dalam dunia kerja khususnya terhadap dunia jasa konstruksi.

b. Proses pembelajaran Pengalaman Kerja Lapangan (PKL) sebagai suatu ajang peningkatan minat dan kemampuan mahasiswa, sangat diharapkan memberikan pengalaman lapangan bagi calon tenaga kerja dan memberikan kesempatan sebesar-besarnya untuk dapat mengaplikasikan ilmu yang telah diperoleh serta untuk mengembangkan ilmu yang dimiliki dalam dunia jasa konstruksi.

c. Bagi kepentingan studi dan penelitian lebih lanjut, bahwa penelitian ini belum mencapai tujuan yang optimal sebagaimana yang diharapkan, karena masih memiliki kekurangan/kelemahan. Oleh karena itu disarankan agar penelitian ini menjadi bahan pembanding bagi penelitian yang sama.

\section{DAFTAR PUSTAKA}

Arikunto, Suharsimi. Manajemen Penelitian. Jakarta Rineka Cipta, 1995.

Jakarta Rineka Cipta, 1995.
Artikel, $\quad$ http://.wordpress.com/2010/03/daftaralamat-smk-dki-jakarta.pdf diakses pada tanggal 13Maret jam 09.20.

Artikel,

http://www.dikti.go.id/Archive2007/kepme ndiknas_no_045u2002.htm diakses pada tanggal 13Maret jam 09.53.

Chourmain, Imam. 2008. Acuan Normatif Penelitian Untuk Penulisan Skripsi, Tesis, dan Disertasi. Jakarta: Al-Haramain Publishing House.

Crites, O.Jhon, Vocational Psychology. (Mc.Graw Book Company: 1969).

Depdiknas UNJ. Pedoman Akademik 2006/2007. Jakarta UNJ 2006

Hurlock, Elizabeth B.Psikologi Perkembangan Suatu Pendekatan Sepanjang Kehidupan (Jakarta; Erlangga, 1980)

Fajri, Em Zul dan ratu Aprilia Senja. Kamus Lengkap Bahasa Indonesia. Jakarta Difa Publisher, tanpa tahun.

H.C Witherington, Terjemahan M. Buchori, Psikologi Pendidikan. (Jakarta; Aksara Baru 1985)

Hamalik, Oemar, Pendidikan Guru Berdasarkan Pendekatan Kompetensi, Jakarta: Bumi Aksara, 2003.

Heni Wahyuwidiyanti, Minat Belajar Siswa Ditinjau Dari Suasana Intelektual Keluarga (Skripsi: 1992)

http://creasoft.files.wordpress.com/2008/04/2min at.pdf diakses pada tanggal 23 April jam 13.10.

http://creasoft.wordpress.com/2010/03/18/konsep -minat/ diakses pada tanggal 20 Maret jam 11.20.

http://file.upi.edu/Direktori/L\%2020FPEB/PRODI. \%20EKONOMI\%20DAN\%20KOPERASI/1 96302211987032\%20\%20NETI\%20BUDI WATI/Analisis\%20Faktorfaktor\%20yang\% 20Mempengruhi $\% 20$ Minat $\% 20$ Siswa $\% 20$ SLTP\%20Melanjutkan\%20ke\%20SMK.pdf diakses pada tanggal 13April jam 11.20. 
http://hennykartika.wordpress.com/category/meto dologi-penelitian/ diakses pada

tanggal 23 April jam 10.14 .

http://maskresno.wordpress.com/2008/01/30/tekn ik-penulisan-instrumen-pengumpulandata/ diakses pada tanggal 23 April jam 16.20 .

http://metodepenelitiianelka07.blogspot.com/201 1/01/minat-dan-bakat-siswa-kesekolah.html diakses pada tanggal 28 April jam 07.20.

http://sdoriza.wordpress.com/2010/04/02/definisikonseptual-variabel-definisi-operasionalvariabel/ diakses pada tanggal 13 April jam 10.20.

http://www.tugaskuliah.info/2009/12/pengaruhperhatian-orang-tua-dan-minat.html diakses pada tanggal 20 April jam 14.15.

http:/ensiklopedia.com/teknik-sipil.html

Hurlock, Elizabeth B, Psikologi Perkembangan: Suatu Pendekatan Sepanjang.

Hilgard's Introduction to Psychology.

L.L Pasaribu.B Simanjuntak, Didaktik dan Metodik (Bandung: Tarsito 1986)

M.Surya, Dasar-dasar Konseling Pendidikan (Yogyakarta; Kota Kembang 1988)

Muhibbin, Syah. Psikologi Pendidikan dan Pendekatan Baru (Bandung, remaja Rosdakarya, 1997)

Peraturan Pelaksanaan Undang-Undang Jasa Konstruksi: PT. Mediatama Saptakarya, Yayasan Penerbit Pekerjaan Umum.
Purwanto, M.Ngalim Psikologi Pendidikan (Bandung: Remaja Rosdakarya,1996)

Ria Riantika Sari.2012, Klasifikasi Bidang Pekerjaan Lulusan Program Studi Pendidikan Teknik Bangunan FT UNJ.

Save M.Dagun, Kamus Besar IImu Pengetahuan (Jakarta. Lembaga Kajian Kebudayaan Nasional)

Saiful Bachri Jamara, Psikologi Belajar, (Jakarta: Rineka Cipta, 2000)

Sudjana. Metode Statika. Bandung. Penerbit Tarsito.

Suhartini; Dewi Suhartini. Prosedur Penelitian Suatu Pendekatan Praktek dan Analisis Minat (Yogyakarta: Pustaka Hidayah, 2001)

Suraji, Achmad. Lembaga pengembangan Jasa Konstruksi Nasional (LPJKN).

Undang-Undang Republik Indonesia No.18 tahun 1999. Jasa Konstruksi:

PT. Mediatama Saptakarya, Yayasan Penerbit Pekerjaan Umum.

Universitas Negeri Jakarta, Pedoman Akademik 2010, Jakarta: Universitas Negeri Jakarta,2010/2011.

Wayan Nurkencana dan PPN Sumartana (Evaluasi Pendidikan:1983)

Witherington, Psikologi Pendidikan. Jakarta, Aksara Baru:1983.a. 